УДК 331:637.5

\title{
APPLIED ASPECTS OF IMPROVING LABOR FORMATION IN MEAT PROCESSING INDUSTRY ENTERPRISES
}

\author{
E. Dragan, A. Berger \\ National University of Food Technologies
}

\begin{tabular}{|c|c|}
\hline Key words: & ABSTRACT \\
\hline $\begin{array}{l}\text { Standardization } \\
\text { Labor } \\
\text { Enterprise } \\
\text { Attestation of jobs } \\
\text { Meat processing industry }\end{array}$ & \multirow{3}{*}{$\begin{array}{l}\text { The article studies the problems of the current state and } \\
\text { development of the organization of labor standardization at } \\
\text { meat processing enterprises. It is justified that the impro- } \\
\text { vement of labor standards should be related to the consi- } \\
\text { deration of the severity of the subject of labor in carrying } \\
\text { out specific operations for workers of different gender. The } \\
\text { shortcomings in the certification of workplaces on working } \\
\text { conditions at various meat processing industries are charac- } \\
\text { terized. Proposals for improving the standardization of labor } \\
\text { of enterprises are justified. }\end{array}$} \\
\hline $\begin{array}{l}\quad \text { Article history: } \\
\text { Received 17.05.2017 } \\
\text { Received in revised form } \\
04.06 .2017 \\
\text { Accepted } 27.06 .2017\end{array}$ & \\
\hline $\begin{array}{l}\text { Corresponding author: } \\
\text { E. Dragan } \\
\text { E-mail: } \\
\text { eidragan@ukr.net }\end{array}$ & \\
\hline $.24263 / 2225$ & \\
\hline
\end{tabular}

\section{ПРИКЛАДНІ АСПЕКТИ УДОСКОНАЛЕННЯ НОРМУВАННЯ ПРАЦІ НА ПІДПРИЕМСТВАХ М'ЯСОПЕРЕРОБНОÏ ГАЛУЗІ}

\author{
О.І. Драган, А.Д. Бергер \\ Національний університет харчових технологій
}

У статті досліджено проблеми сучасного стану та розвитку організаиії нормування праиі на підприємствах м'ясопереробної галузі. Обтрунтовано, що удосконалення нормування праці повинно бути пов'язано з урахуванням ваги предмету пращі при здійсненні конкретних операџій для пращівників різної статі. Охарактеризовані недоліки при проведенні атестачї робочих місиь за умовами праці на різних виробництвах м'ясопереробної галузі. Обгрунтовані пропозищії щодо удосконалення нормування праці підприсмств.

Ключові слова: нормування, праия, підприємство, атестачія робочих місць, м'ясопереробна галузь.

Постановка проблеми. У Кодексі про працю України (глава VI «Нормування праці») в стст. 85, 86, 87, 88, 89, що присвячені даному питанню, наголошується, що основну відповідальність за організацію і нормування праці на виробництвах повністю бере на себе керівництво підприємств [1]. 
Тому сьогодні функція нормування праці стала повною прерогативою підприємства. Водночас децентралізація управління економікою не повинна призводити до втрати державних функцій щодо визначення єдиних принципів нормування праці, загальних вимог соціального захисту робітників при підвищенні напруженості норм та інтенсивності праці. Реалізація цих принципів вимагає впровадження нових підходів до роботи з нормування праці.

Аналіз останніх досліджень і публікацій. Питання нормування праці на підприємствах були розглянуті М.А. Волгіним, В.В. Вудвудом, Г.Т. Завіновською, Л.В. Синяєвою, О.В. Коломієць, В.Г. Донцовою, Ю.Г. Одеговим, Р.П. Колосової, О.А. Грішнової, А.М. Колот та іншими. Однак сучасні підходи вимагають від прикладних досліджень врахування галузевих особливостей щодо розроблення пропозицій з удосконалення нормування праці з метою їх практичного застосування на підприємствах.

Дослідження питання організації праці на підприємствах м'ясопереробної галузі свідчить про наявність недоліків і незадоволення працівників ії̈ сучасним станом. Основними причинами незадоволення працівників $є$ високий рівень ручної праці у забійних цехах, низька мотивація праці, високий рівень напруженості праці, застосування застарілих норм праці, високий рівень плинності робітничих кадрів тощо.

Мета статті: дослідити проблеми сучасного стану нормування праці та обгрунтувати пропозиції щодо удосконалення нормування праці на підприємствах м'ясопереробної галузі.

Викладення основних результатів дослідження. У сучасних умовах нормування праці на підприємствах м'ясопереробної галузі знаходиться у занепаді. Надвитратний характер економіки підприємств, низький рівень тарифних ставок стали гальмом для використання у виробництві ефективних організаційних рішень і застосування науково-обгрунтованих норм витрат праці. На більшості підприємств норми праці не переглядалися 10 років, а на окремі роботи вони взагалі були відсутні.

Низький рівень нормування праці також обумовлений недостатнім забезпеченням підприємств галузі висококваліфікованими кадрами - інженерами 3 нормування праці, чисельність яких за останні 15 років скоротилася майже в 10 разів. Як наслідок, атестація робочих місць на більшості підприємств м'ясопереробної галузі за останні 10 років не проводиться (за необхідності проведення атестації робочих місць не менше 2 разів за 5 років [2, с.32]). Слід зазначити, що атестація робочих місць на підприємствах м'ясопереробної галузі проводилася за загальним положенням про атестацію робочих місць, яке не враховувало галузевих особливостей: важкості і напруженості трудових процесів; забруднення повітря аміаком, чадним газом, сірчаним ангідридом, свинцем, кислотами, озоном; забруднення повітря хвороботворною мікрофлорою, сальмонельозом тощо. Важливість розроблення положення про атестацію робочих місць на підприємствах м'ясопереробної галузі викликана впровадженням міжнародних стандартів НАCCP і $є$ його обов'язковою частиною щодо виявлення ризиків на виробництві.

Більшість керівників підприємств м'ясопереробної галузі ліквідували служби нормування праці. Найчастіше ця робота виконується на рівні цехів, 
тому не переглядаються норми витрат праці, не проводяться заходи щодо раціоналізації робочих місць. Погіршення стану нормування праці на підприємствах поглиблюється за рахунок недосконалості господарського механізму, який дає змогу збільшувати ціни на продукцію, не знижуючи при цьому витрати виробництва, тощо. Через низку об'єктивних і суб'єктивних причин знижено рівень економічної роботи підприємств галузі. Замість надмірної жорсткої «регламентації» змісту організації і нормування праці, порядку встановлення та перегляду відповідних нормативів протягом короткого часу в Україні сталася їі повна децентралізація.

Сдиний наказ «Про заходи щодо поліпшення нормування праці» від 28 грудня 2000 року № 361/7, якій був виданий Міністерством праці та соціальної політики України і Міністерством економіки України, передбачав, що з метою поліпшення нормування праці як важливої складової підвищення ефективності виробництва, зростання продуктивності праці, посилення соціальної захищеності працівників, забезпечення оптимального співвідношення між мірою праці та їі оплатою, більш ефективного використання робочого часу за рахунок скорочення його непродуктивних витрат, розвитку та поширення національної нормативної бази з праці, посилення організаційнометодичної і практичної допомоги підприємствам, організаціям 3 питань нормування праці та на виконання протоколу № 25 засідання Урядового комітету соціального та гуманітарного розвитку від 14.02 .2000 р. (п.5), всі організації державної та комунальної форм власності повинні проаналізувати та вжити заходів щодо підвищення ефективності роботи головних організацій 3 розроблення нормативних і методичних матеріалів 3 нормування праці, за необхідності - вирішити питання про створення підрозділів, що мають забезпечити цю роботу [3, с.123].

Фактично держава нині не надає приватним і колективним підприємствам ні методичної, ні нормативно-інформаційної допомоги. Існує реальна загроза втрати здобутків вітчизняних учених і фахівців у цій галузі. Значною мірою залишаються незатребуваними результати наукових і прикладних досліджень 3 питань атестації робочих місць, раціоналізації трудових процесів на підприємствах м'ясної промисловості.

Наступна причина пов'язана 3 тим, що рівень середньої заробітної плати та іiі частка в собівартості $\epsilon$ надто низькими - $2-4 \%$, що не спонукає керівництво підприємств до поліпшення нормування праці.

Не сприяють максимальному використанню резервів виробництва на основі поліпшення якості нормування та розширення його сфери і такі чинники, як нестабільність економічного середовища, необхідність проведення реструктуризації виробництва, недооцінка ролі нормування праці як важливої складової організації праці та виробництва, важливого чинника регламентації праці й удосконалення соціально-трудових відносин. Останнє є наслідком недостатньої фахової підготовки керівників підприємств та їхніх структурних підрозділів.

Проте цілком очевидно, що для виробництва м'ясної продукції високої якості і доступної для широкого кола споживачів необхідне постійне зниження витрат на іï виробництво, у тому числі за рахунок передовсім викорис- 
тання ресурсів праці. Світовий і вітчизняний досвід переконують у тому, що без нормативного регулювання робочого часу за тривалістю, рівнем напруженості (інтенсивності) неможливе ефективне виробництво.

До набуття Україною державності в м'ясопереробній галузі в централізованому порядку Всесоюзним науково-дослідним інститутом м'ясної і молочної промисловості був створений банк даних норм часу для всіх виробництв: м'ясожирового, ковбасного, консервного, технічних фабрикатів, птахопереробного тощо. Дані норми часу передбачають нормативи праці і детальний опис типових робочих місць, застосування технологічного обладнання, пристроїв, які доцільно використовувати при розрахунку норм часу та виробітку на діючих підприємствах галузі.

Недоліком типових норм часу $є$ недостатнє врахування ваги предмету праці при здійсненні конкретних операцій для працівників різної статі та підлітків. Наприклад, операція - обвалювання м'яса на кістках (яловичини II категоріі). Вага напівтуші в середньому становить 75 кг (відповідно за частинами: шийна частина -11 кг; поперекова -9 кг; тазостегнова -15 кг; лопаткова - 12 кг; крижова і грудореберна - 30 кг). У середньому типова норма виробітку становить 2 т м'яса на кістках за 8 годин. Якщо розглядати послідовність виконання операції — відділення м'яса від кісток кожної частини напівтуші, то потрібно кожну частину підняти не менше $3-4$ разів. Таким чином, робітник за зміну піднімає предмет праці вагою 6-8 т для виконання норми виробітку. Дослідження свідчать, що обвалювальники м'яса, відпрацювавши 6-8 років після професійно-технічного училища, переходять працювати на інші дільниці цехів через різні хвороби, що пов'язані з важкістю праці, або звільняються з підприємства. Це стосується також майже всіх інших робітників, які виконують ручні, машинно-ручні операції, що пов'язані з переробленням важких предметів праці. Такі ж самі типові норми виробітку на технологічні операції застосовуються і в країнах $\mathrm{CC}$, що сприяє високій плинності кадрів - до 25-30\% [4, с.94]. Все це робить дані професії робітників непривабливими та дефіцитними як для України, так і для країн СС.

На підприємствах м'ясопереробної галузі обвалювальниками м'яса, як правило, працюють жінки, для яких типові норми виробітку є порушенням вимог охорони праці, що призводить до скорочення тривалості життя робітників. У зв'язку з цим виникає нагальна проблема - проведення атестації робочих місць та розроблення нових типових норм виробітку на всі ручні i машинно-ручні операції з дотриманням сучасних правил охорони праці, а також розроблення нових типових норм виробітку з урахуванням статі та віку працівників, що не передбачається чинними типовими нормативами праці для всіх виробництв підприємств. Так, згідно з чинною з 1 січня 2002 року Гігієнічною класифікацією праці за показниками важкості трудового процесу розподіляються на такі показники: при загальному навантаженні за участю м'язів корпусу, рук та ніг при переміщенні вантажу на відстань до 5 м допустиме (середнє фізичне навантаження) становить: для чоловіків - $25 \mathrm{~T} \cdot \mathrm{m}$, для жінок - 15 т•м. При важкій праці 2-го ступеня загальне навантаження для чоловіків складає понад 35 т·м; для жінок - понад 25 т·м (табл. 1) [5]. 
Оскільки передбачаються різні норми навантаження для жінок і чоловіків на цих процесах, то, відповідно, і норми виробітку повинні бути меншими на $40 \%(25: 35 \times 100=60 \%)$.

Таблиия 1. Класи умов праці за показниками важкості трудового процесу, [5, с. 366]

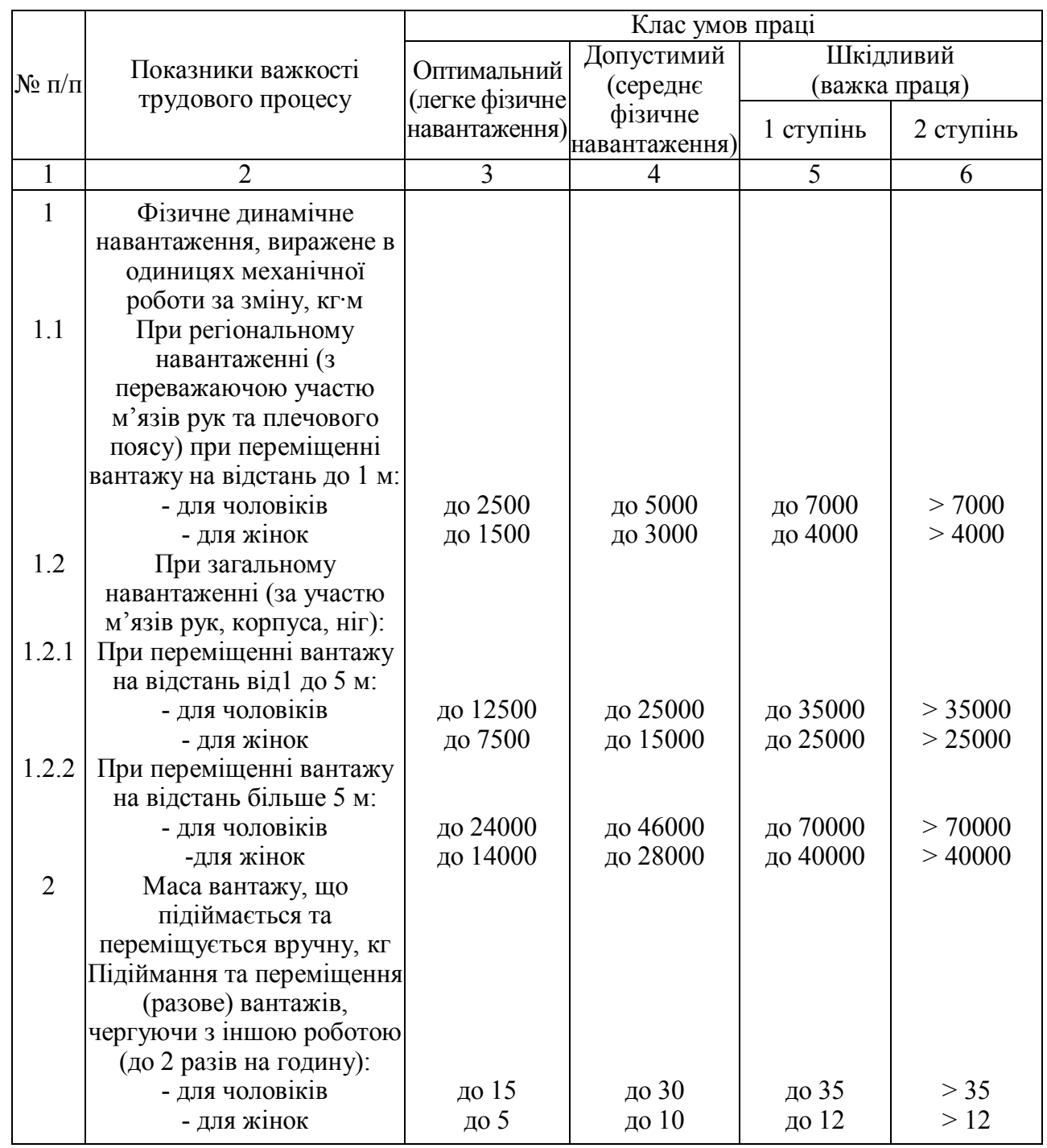

При дослідженні шкідливих факторів на підприємствах м'ясопереробної галузі екологічними лабораторіями та обласними санітарно-епідеміологічними станціями виявлено такі порушення:

- наявність шкідливих хімічних речовин у повітрі робочої зони: аміак 4 клас небезпеки; сірководень - 2 класу небезпеки; озон - 1 клас небезпеки; оксид азоту - 3 клас небезпеки; сірчаний ангідрид - 4 клас небезпеки; оксид вуглецю - 4 клас небезпеки; оксид заліза - 3 клас небезпеки; марганець - 2 клас небезпеки; 
- наявність біологічного фактору: мікробного аерозолю 4 класу небезпеки у повітрі робочої зони в забійному, шкуроконсервувальному, кишковому цехів, цеху технічних фабрикатів;

- наявність вібрації при роботі на електропилах;

- наявність шуму при роботі на подрібнюючому обладнанні;

- стан мікроклімату у приміщеннях цехів: завищена вологість повітря в кишковому, субпродуктовому, забійному, жировому; підвищення температури в термічних відділеннях понад $+40^{\circ} \mathrm{C}$, недотримання температурних режимів у холодильнику нижче $-10^{\circ} \mathrm{C}$;

- нервово-емоційна напруженість у забійному цеху;

- важкість трудових процесів майже у всіх цехах підприємства.

На деяких операціях спостерігається не тільки динамічне навантаження, але й статичне. Наприклад, робоча поза характеризується нахилом положення за $30^{\circ}$ понад $50 \%$ тривалості зміни. При проведенні атестації робочих місць не враховується поєднання динамічного і статичного навантаження робітника. Отже, виникає потреба розроблення методичних рекомендацій щодо комплексної оцінки сумарної дії факторів виробничого середовища та характеру виконання кожної операції на підприємствах м'ясної промисловості. Крім того, необхідно розробити рекомендації щодо зниження впливу наявних шкідливих факторів на здоров'я працюючих.

У сучасних умовах українське суспільство $\epsilon$ гендерно асиметричним на користь жінок. Ці ж тенденції можна побачити і на підприємствах м'ясопереробної галузі, де працює $70-90 \%$ жінок [6, с. 10].

Гендерна асиметрія - це соціальне явище, яке відображає об'єктивну закономірність кількісного розподілу чоловіків і жінок у соціальній структурі суспільства і у всіх сферах життедіяльності. В основі гендерної асиметрії лежить біологічна і фізіологічна різниця за ознакою статі, конкретні соціально-економічні і соціальні умови, реальна демографічна ситуація в країні. Як результат, у 2016 р. - кількісне переваження жінок на $16 \%$ у структурі населення, яке об'єднує дві гендерні єдності: жіночу і чоловічу [7].

У ринкових умовах статус жінок різко погіршився, скоротилися можливості професійного і кар'єрного зростання. При цьому необхідно враховувати, що проблема кар'єрного зростання жінок торкається всіх без винятку сфер життя суспільства: економічного, політичного, соціального, духовного. Стан економіки країни - вирішальний фактор суспільного життя, який радикально впливає на становище чоловіків і жінок. Саме в економіці проходять найбільш кількісні і якісні зміни в гендерній асиметрії- зберігається переваження жінок, їх соціальна дискримінація стала сильнішою.

Стаття 24 Конституції України про гендерну рівність, крім прав і свобод, визначає право жінки і чоловіка на рівність як самостійне право людини на повагу, що має бути гарантовано кожному. Стаття 24 забезпечує: надання жінкам рівних $з$ чоловіками можливостей у громадсько-політичній і культурній діяльності; у здобутті освіти і професійній підготовці; у праці та винагороді за неї; спеціальними заходами щодо охорони праці і здоров'я жінок; встановлення пенсійних пільг; створення умов, які дають жінкам можливість поєднувати працю 3 материнством; правовим захистом, матеріальною й 
моральною підтримкою материнства і дитинства, включаючи надання оплачуваних відпусток та інших пільг.

У 2005 р. в Україні було прийнято Закон № 2866-IV «Про забезпечення рівних прав та можливостей жінок і чоловіків». Значення цього документа полягає в тому, що: 1) сам факт його розробки є свідченням визначення різного впливу публічної політики на чоловіків та жінок, внаслідок чого економічний та соціальний статус жінок по відношенню до чоловіків постійно знижується; 2) він пропонує впливати на зміни в економіці через гендерний аналіз для розкриття наявних та потенційних соціальних проблем i пошуку рішень їх оптимального розв'язання [8].

Серед гендерних проблем слід виділити наявність гендерної асиметрії на ринку праці — менший рівень оплати праці жінок, поєднання жінками професійних та сімейних обов'язків, наявність дискримінації у зайнятості за ознакою статі, незабезпечення рівних можливостей для жінок та чоловіків на ринку праці. Матеріальні міркування є домінуючими, а в багатьох випадках єдиним мотивом професійної діяльності українських жінок. Жінки показують свою суттєву адаптованість до зміни умов, більш схильні до співпраці, гнучкості, компромісу, погоджуються реалізувати свою трудову діяльність у менш престижних і більш складних і тяжких умовах праці. Все стосується й працівниць на підприємствах м’ясопереробної галузі.

\section{Висновки}

В умовах інтеграції української економіки у світовий економічний простір зростає рівень конкуренції між підприємствами-виробниками м'ясної продукції, що вимагає активізації роботи щодо економії трудових і матеріальних ресурсів на основі застосування нової техніки та прогресивної технології, підвищення організаційного рівня виробництва й формування інноваційного потенціалу. Вирішенням цих питань є розроблення пропозицій, які повинні включати: максимальне розширення сфери нормування праці; обгрунтування норм здійснювати з урахуванням соціальних, психофізіологічних чинників, статі та віку працівників; проведення коригування типових галузевих нормативів часу 3 урахуванням вимог охорони праці та техніки безпеки; посилення контролю державної інспекції праці за рівнем обгрунтованості норм трудових витрат та умов праці на підприємствах галузі 3 метою недопущення перевищення їх допустимих значень; створення науковометодичної основи соціально-економічної оптимізації норм праці для жінок; заборону підвищення норм праці без проведення організаційно-технічних заходів у виробництві; удосконалення методики розрахунку відрядних розцінок з урахуванням коефіцієнту напруженості норм та ін.

\section{Література}

1. Науково-практичний коментар Кодексу законів про працю України. Станом на 15.01.2017 р. - Київ : ЦУЛ, 2017. - 312 с.

2. Інформаційний бюлетень 3 охорони праці. - Київ : ННДІОП.- 2015.— № 2.C. $32-33$. 
3. Про заходи поліпшення нормування праці: наказ Міністерства праці та соціальної політики України і Міністерства економіки України від 28 грудня 2000 р. №361/7. [Електронний ресурс]: Режим доступу до ресурсу: uazakon.com>documents/date_2c/pg_isgmsd.htm.

4. Флагман м'ясної індустрії України [За ред. А. Степаненко]. - Вінниця : «Універсум-Вінниця», 2000. - 292 с.

5. Гігієнічна класифікація праці за показниками шкідливості та небезпечності факторів виробничого середовища, важкості та напруженості трудового процесу: Наказ Міністерства охорони здоров’я від 27 грудня 2001 року № 528. - Київ : Офіційне видання. 2001. - $47 \mathrm{c}$.

6. Попов B.I. Особенности работы мясоперерабатывающих предприятий в современных условиях // Мясной бизнес. — № 4(33).-2005. - С. 10-11.

7. Демографія та соціальна статистика «Населення та міграція» (оновлена на 01.01.2017 р.) [Електронний ресурс]. - Режим доступу до ресурсу: http://www.ukrstat.gov.ua.

8. Про забезпечення рівних прав та можливостей жінок і чоловіків: Закон України №2866-IV// ВР України. — 2005.— № 52. 